\title{
The Role of Fibrinolytic Factors in Ischaemia
}

\author{
M. PANDOLFI and A. AL-RUSHOOD \\ Saudi Arabia
}

\begin{abstract}
Summary
The fibrinolytic system is an enzymatic cascade system whose activation leads to formation of a trypsin-like serine protease, plasmin, which splits insoluble fibrin into soluble degradation products. It is believed that the main function of fibrinolysis is defence against thrombotic occlusion of vessels and dissolution of thrombi once they are formed (thrombolysis).

The authors review the recent literature providing evidence that fibrinolysis plays a role in the pathogenesis of vascular occlusions. From earlier studies based on global assay methods it is known that fibrinolysis is depressed in patients with vascular occlusions. Selective assay methods show that almost invariably the fibrinolytic activity of these patients is depressed either following increased levels of fibrinolytic inhibitors (mainly plasminogen activator inhibitor 1 or PAI-1) and/or decreased levels of a plasminogen activator (tissue plasminogen activator or t-PA). In a few cases the molecule of plasminogen shows a conformational abnormality making it less susceptible to conversion to plasmin.

In the last decade numerous studies have been published showing a connection between a depressed fibrinolysis and venous thrombosis. In patients with coronary artery occlusion fibrinolysis is depressed mainly because of increased levels of PAI-1. Hypertriglyceridaemia seems to aggravate the defective fibrinolysis. There is also evidence of a decreased fibrinolysis in patients with peripheral ischaemic diseases.

A depressed fibrinolysis has also been documented in states predisposing to vascular occlusions. Thus lwo levels of t-PA/increased levels of PAI-1 have been found in obesity, diabetes mellitus, postoperative states, SLE, malignancies, and miscellaneous diseases often complicated with thrombosis such as Behçet's syndrome. In pregnancy fibrinolysis is depressed because of the presence in blood of PIA-2, an inhibitor of plasminogen activators secreted by the placenta.
\end{abstract}

\section{The Fibrinolytic System}

The fibrinolytic system is an enzymatic cascade system whose activation leads to formation of a trypsin-like serine protease, plasmin, which is capable of degrading fibrin as well as fibrinogen, factor V and VIII. It is believed that the main function of fibrinolysis is defence against thrombotic occlusion of vessels, dissolution of thrombi once they are formed (thrombolysis) and resolution of clots and fibrinous exudates occurring in various parts of the body.

\section{Activators of fibrinolysis}

A simplified scheme of the fibrinolytic system in man is shown in Figure 1. 


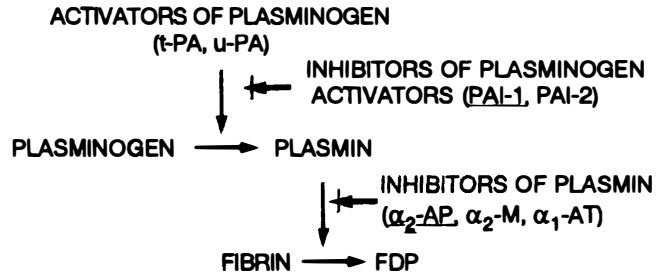

Fig. 1. A simplified scheme of the fibrinolytic system.

Plasmin splits fibrin into soluble fragments (fibrin degradation products-FDP) of different size. Plasmin results from activation of the proenzyme plasminogen, a $\beta_{2}$-glycoprotein with molecular weight of about $90 \mathrm{kD}^{1}$ which is synthetised in the liver. ${ }^{2}$ It tends to be adsorbed to fibrin, the site at which the bulk of plasminogen activation occurs.

Circulating blood contains two types of plasminogen activators: tissue type activator (t-PA) and urinary activator or urokinase (uPA). Both activators may be present in native single chain forms: weakly active sc t-PA ${ }^{3}$ with a molecular weight of $60 \mathrm{kD}$, and sc u-PA (prourokinase) with a molecular weight of $-54 \mathrm{kD}$ which is devoided of enzymatic activity. ${ }^{4}$ An important functional difference between the two activators is that t-PA binds to fibrin which it needs to activate plasminogen while u-PA does not bind to fibrin and is capable of activating plasminogen in absence of fibrin. During activation of fibrinolysis both native forms are converted into the active two chain t-PA and u-PA (tc t-PA and tc u-PA).

T-PA is produced and stored in the endothelium of certain blood vessels where it can be demonstrated histochemically. ${ }^{5}$ From the vascular endothelium t-PA is continously released into the circulation such release being enhanced by a variety of stimuli notably venous stasis ${ }^{6}$ and physical exercise. ${ }^{7}$ The concentration of t-PA antigen in plasma is low, about $5 \mu \mathrm{g} / \mathrm{L}$. It is believed that t-PA plays the central role in maintaining the patency of the vascular tree by dissolving obstructing fibrin deposits or promoting the lysis of occluding thrombi.

U-PA is produced mainly by the kidney and excreted with the urine. Its main role is probably that of maintaining the urinary excretion pathways free from obstructing fibrin. Plasma contains minute amounts of u-PA mainly sc u-PA. ${ }^{8}$ A variety of other cells such as malig- nant cells ${ }^{9}$ and corneal epithelium ${ }^{10}$ have been shown to produce u-PA.

The fibrinolytic system can be activated by kallikrein as well as by F.XII of coagulation (intrinsic activation system). ${ }^{11,12}$ The pathophysiological role-if any-of the intrinsic activation system is not clarified.

\section{Regulation of fibrinolysis. Fibrinolytic inhibitors}

Since plasmin is capable of degrading proteins other than plasmin it is necessary to confine its action to its primary substrate i.e. fibrin. Furthermore the effectiveness of the fibrinolytic system needs constant regulation since a too pronounced activity leads to a haemorrhagic diathesis, while a depressed activity leads to thrombosis. The mechanisms regulating fibrinolysis have been the object of comprehensive reviews. ${ }^{13-17}$

While circulating in blood as free enzymes the activity of t-PA is weak. When fibrin is formed, plasminogen and t-PA are bound to fibrin. Fibrin bound t-PA increases 200 times its cathalytic activity and rapidly converts into plasmin the fibrin bound plasminogen. The result is a local fibrinolysis. Plasmin also converts the inactive sc u-PA into active tc u-PA which takes part in the dissolution of fibrin. However, the role played by u-PA in fibrin dissolution inside the vascular tree is probably ancillary.

The fibrinolytic process is restrained at two different levels by two classes of inhibitory agents present in plasma: the inhibitors of plasminogen activators, ${ }^{18}$ and the inhibitors of plasmin. The main plasminogen activator inhibitor (PAI-1) is contained in the vascular endothelium and in the platelet alpha granules; it immediately binds t-PA and u-PA. In normal conditions it binds $95 \%$ of the circulating t-PA forming a complex with molecular weight of $110 \mathrm{kD} .^{7}$ Changes in PAI-1 plasma levels rather than changes in t-PA have been recently related to diurnal variations of the fibrinolytic activity. ${ }^{19}$ PAI-2 has probably a secondary importance being secreted by placenta and being present only in plasma of pregnant women. However, PAI-2 has recently been found in the plasma of some men and non-pregnant women. ${ }^{20}$

In addition to its anticoagulant activity, 
activated protein C (APC) stimulates fibrinolysis both in vitro and in vivo ${ }^{21,22}$ by binding PAI-1 thus acting as an inhibitor of inhibitor' ${ }^{23} \mathrm{~A}$ similar action as protein $\mathrm{S}$ which acts as a cofactor of APC. ${ }^{24}$

The primary inhibitor of plasmin, $\alpha_{2}$-antiplasmin $\left(\alpha_{2}-\mathrm{AP}\right)^{25}$ rapidly forms a complex with circulating plasmin. In case of massive formation of plasmin-as during thrombolytic treatment with streptokinase or in disseminated intravascular coagulation-an exhaustion of available $\alpha_{2}$-AP occurs. The excess of plasmin is then complexed by $\alpha_{2}$-macroglobulin which functions as a reserve ('second defence line') inhibitor of plasmin. ${ }^{26}$ $\mathrm{A}_{2}$-AP inhibits fibrinolysis also by preventing adsorption of plasminogen to fibrin, an essential step of physiological fibrinolysis.

$\mathrm{C} 1$ inhibitor is known to activate components of the complement $\mathrm{C} 1 \mathrm{~s}$ and $\mathrm{C} 1 \mathrm{r}$; it also inhibits clotting factor XIIa, XIa and kallikrein. Furthermore it reacts with plasmin and with t-PA although at such low rates that its significance as inhibitor of fibrinolysis is uncertain. $^{27}$

The balance between the profibrinolytic and antifibrinolitic activity is regulated by the synthesis of these agents and by their release into circulation. Synthesis and release have been found to be mediated by a number of substances such as thrombin, histamin, epinephrine. ${ }^{28}$ Another mechanism of regulation is the presence of binding sites for plasminogen, t-PA u-PA ${ }^{29,30}$ on cellular membranes.

\section{Clinical significance of fibrinolysis. Possible role in the pathogenesis of vascular occlusions}

In the mid-50s there was enough knowledge on the fibrinolytic system to allow Astrup to present a scheme of fibrinolysis which was similar to the present one,${ }^{31}$ the only significant difference being that inhibitors of plasminogen activators were not reported. A number of functions have been attributed to the fibrinolytic system.

Fibrin deposits which may form within the vascular lumen are believed to be dissolved by an intact fibrinolytic system before they grow enough to threaten the patency of the vessel. ${ }^{32}$ A corollary to the antithrombotic action of the fibrinolytic system is that administration of purified fibrinolytic enzymes brings about dissolution of occluding thrombi (therapeutic thrombolysis).

In inflammation and trauma fibrin is usually formed. During the healing process fibrin, which may act as matrix for neoformed vessels; is gradually broken down by the systemic and local fibrinolysis. A timely dissolution of fibrin is important to avoid bleeding or scarring. ${ }^{31}$

The role of fibrinolysis in tumour growth is unclear. Tumoural cells secrete $\mathrm{u}-\mathrm{PA}^{9}$ and it is generally known that certain tumours are surrounded by a wall of fibrin which may have a containment action but which may also act as a matrix for vascular proliferation.

Activators of fibrinolysis, mainly u-PA, have been found in disparate areas of the body such as kidney, prostate, cornea, pleura, aqueous humour..$^{33}$ Their function is probably that of maintaining the patency of small ducts and preventing the development of adherence between surfaces.

The most manifest clinical significance of fibrinolysis however, is its action of preventing vascular occlusion by thrombi. A corollary of such action is that a depressed fibrinolysis promotes thrombosis. To verify this hypothesis numerous studies have been done with the aim of detecting a decreased fibrinolysis in patients suffering from vascular occlusions of various type or presenting conditions predisposing to vascular occlusion.

\section{Fibrinolysis and Vascular Occlusions}

The studies directed towards establishing a link between vascular occlusion and depressed fibrinolysis can be divided in two groups, i.e. those investigating the fibrinolytic system in patients actually suffering from vascular occlusions and those dealing with the fibrinolytic system in conditions predisposing to vascular occlusions.

\section{A. The fibrinolytic system of patients in whom vascular occlusion is the primary disease}

\section{Venous thrombosis}

The first unequivocal report linking thrombosis with depressed fibrinolysis was published in 1961 by Nilsson and associates. ${ }^{34}$ These authors described a young patient with 
severe and widespread venous thrombosis who showed a strongly increased plasma level of an inhibitor of plasminogen activation. The inhibitor was most likely PAI-1, at that time not yet identified. Later the same author described four more patients including two uniovular twins affected by recurrent severe thrombosis since childhood with a high blood content of inhibitor of plasminogen activation. ${ }^{35}$ Histochemistry of vein specimens obtained by biopsy from patients with venous thrombosis showed a decreased plasminogen activator activity of the vein wall. ${ }^{36}$ Increased levels of fibrinolytic inhibitor was found in the plasma of a patient affected by retinal vein occlusion in both eyes. ${ }^{37}$

In a large series of patients with idiopathic venous thrombosis it was found that a large number of these patients had a defective fibrinolysis in the blood and/or vein walls. ${ }^{38}$ The methods used were functional i.e. determination of the spontaneous fibrinolytic activity of plasma and the activity following venous stasis, as well as a histochemical method to assess the activity in the wall of vein specimens obtained by biopsy. These finding were confirmed by subsequent reports. ${ }^{43}$

Progress in the 80s led to the discovery and characterisation of PAI-1, review in ${ }^{18}$ the fast acting inhibitor of t-PA. It was found that PAI-1 masked the fibrinolytic response to venous stasis. ${ }^{44}$ Two mechanisms of defective fibrinolysis in thrombosis patients were identified i.e. low levels of t-PA or increased concentration of PAI-1. ${ }^{45-47}$

Of special interest is the occurrence of either type of defective fibrinolysis associated with recurrent thrombosis in members of the same family. ${ }^{42,43,48-51}$ The defect seems to be inherited according to an autosomal dominant mode with high penetrance. Nilsson and Tengborn ${ }^{49}$ consider it odd that an inherited disorder should be due to an increased synthesis of inhibitor and hypothetised the presence of an abnormal inhibitor with increased affinity for t-PA.

In some cases recurrent venous thrombosis may be associated with the presence of an abnormal plasminogen molecule. ${ }^{52-54}$ However, the associated defective plasminogenthrombosis seems weak considering that family members of the patients reported had a decreased plasminogen activity (down to $5-10 \%$ of the normal) and did not show thrombosis. A normal plasminogen molecule but in low amounts was also found to be associated with thrombosis. ${ }^{55}$

Hereditary low levels of protein $\mathrm{C}^{56}$ and protein $\mathrm{S}^{57}$ are accompanied by an increased incidence of venous thrombosis. However, because these two proteins connected mainly with inhibition of coagulation it is uncertain whether the supposed protecting action against thrombosis is mainly due to their anticoagulant action rather than to their profibrinolytic activity.

\section{Coronary artery occlusion}

In the last decade endoscopic studies have shown that thrombosis is not a sequel to myocardial infarction (MI) as previously supposed, but the precipitating factor in MI and unstable angina. ${ }^{58.59}$ This evidence, together with the favourable results obtained with modern thrombolytic therapy, ${ }^{60}$ attracted new interest on the fibrinolytic system in patients with coronary artery disease. The results of earlier studies using only functional methods of assessment suggested decreased fibrinolytic activity in these patients. ${ }^{61-63}$ Recent results ${ }^{64-66}$ provide evidence that the reduced fibrinolysis is mainly due to increased plasma levels of PAI-1, and in younger patients also to defective t-PA release from the vessels. ${ }^{65}$ Depressed fibrinolysis seems also to predispose to reinfarction. ${ }^{66}$ Interestingly, numerous known risk factors for MI such as cigarette smoking, ${ }^{67}$ hyperlipoproteinaemia ${ }^{68,69}$ obesity (see below) are associated with decreased fibrinolytic activity. In particular, a positive correlation between PAI-1 levels and plasma triglycerides has been found. ${ }^{64}$ However, a recent study, ${ }^{70}$ while confirming the finding that PAI-1 activity is positively correlated with levels of triglycerides, failed to observe either increased PAI-1 or decreased t-PA in a group of 65 men with angiographically documented coronary artery disease. Kirschstein et $a l .{ }^{71}$ found that restenosis after percutaneous transluminal coronary angioplasty was significantly more frequent in patients who devloped lower fibrinolytic activity and released lesser amount of t-PA following venous stasis. 
Depressed fibrinolysis has been reported also in ischaemic cerebrovascular diseases. ${ }^{72,73}$

\section{Peripheral schaemic diseases}

According to a recent report there is an association between deficient release of t-PA following venous stasis and occlusive arterial disease of the upper limbs. ${ }^{74}$ An abnormal plasminogen molecule in patients with upper extremity ischaemia has also been reported. ${ }^{75}$ In a large series of patients with peripheral vascular diseases both the resting fibrinolytic activity of plasma and the activity increase following venous stasis were significantly lower in the patient group than in controls. ${ }^{76}$ No information is available on changes, if any, in the levels of PAI-1. Histochemical evaluation of the plasminogen activator activity in leg arteries of patients undergoing below-knee amputation revealed an abnormally low activity. ${ }^{77}$ However, in collateral arteries plasminogen activator activity was as high as that of arteries in other parts of the body, a result suggesting that atherosclerosis is not accompanied by a general suppression of plasminogen activator activity in the arterial vascular tree. Experimental ischaemia has been found to decrease the fibrinolytic activity of the femoral artery of rat. ${ }^{78}$

\section{B. The Fibrinolytic System in Conditions Predisposing to Vascular Occlusions}

1. Pregnancy

It is known that pregnancy is a predisposing factor to thrombosis. The fibrinolytic system in pregnant women becomes increasingly depressed during pregnancy ${ }^{79}$ reponds poorly to venous stasis $^{80}$ and rapidly reverts to normal values after delivery following placenta separation. ${ }^{81}$ Placenta is rich in PAI- ${ }^{82}$ and PAI-2 ${ }^{83}$ These inhibitors pass into the circulation $^{84,85}$ leading to a depressed fibrinolytic activity.

\section{Metabolic disorders}

Human obesity is affected by a higher prevalence of arterial and venous thrombosis. ${ }^{86}$ There are several reports showing that obese subjects have a depressed fibrinolysis as shown by a low spontaneous plasma fibrinolytic activity and defective fibrinolytic response to venous stasis. ${ }^{87-89}$ Increased levels of inhibitors of plasminogen activator has been suggested to be behind the depression of fibrinolysis. ${ }^{87,88}$ Interestingly, a positive correlation has been found between the levels of serum triglycerides and PAI-1 activity. ${ }^{88}$ Weight reduction has been found to revert the fibrinolytic defect in obese subjects ${ }^{90}$ while physical exercise augments the fibrinolytic response to venous occlusion in healthy adults. ${ }^{91}$ There are numerous reports suggesting that lipaemia inhibits fibrinolysis. ${ }^{92}$ Recently it has been found that lipoprotein, an independent risk factor for ischaemic heart disease, binds to the plasminogen receptors on endothelial cells thereby hindering the mechanism of thrombolysis. ${ }^{93}$ No reports are available connecting the depressed fibrinolysis in obese subjects and the occurrence of thrombosis.

\section{Post-operative states}

Like trauma, ${ }^{94,95}$ surgery has been reported to produce a pronounced depression of fibrinolysis. ${ }^{96-98}$ If fibrinolysis is already depressed, the consequence may be a postoperative venous thrombosis. There are several studies on the fibrinolytic system in patients before surgery in order to evaluate the risk of postoperative thrombotic complications. ${ }^{99-104}$ These studies, which are based on functional assay methods, report a direct relationship between low pre-operative fibrinolysis and an increased risk of developing thrombosis after surgery. More recent studies show that the depressed fibrinolysis observed before and in connection with surgery is largey due to increase in the plasma levels of PAI-1. ${ }^{105-109}$

\section{Systemic lupus erythematosus (SLE)}

Patients with autoimmune diseases (SLE, rheumatoid arthritis, scleroderma) are prone to venous and arterial thrombosis. ${ }^{110}$ Such risk has been found to be related to an acquired autoantibody termed lupus anticoagulant or LA which is present in a moderate $(10-15 \%)$ percentage of these patients. ${ }^{82}$ LA consists of IgG or IgM antibodies against phospholipids which in vivo act as a thrombogenic factor despite their in vitro anticoagulant activity. ${ }^{111}$ Patients with SLE tend to have a depressed spontaneous fibrinolytic activity of the blood and to respond poorly to fibrinolytic stimuli 
such as venous stasis. ${ }^{112-114}$ Defective fibrinolysis seems to correlate with the severity of the disease since it is absent in patients with mild forms of SLE. ${ }^{115}$ The reason for depressed fibrinolytic activity seems mainly to be in increased levels of inhibitors of plasminogen activation. ${ }^{114}$ Concomitant increased von Willebrand factor levels seem to indicate an endothelial cell dysfunction in patients with lupus anticoagulant. ${ }^{114}$ However a recent report failed to show that patients with SLE and thrombosis have a fibrinolysis lower than controls. $^{116}$

\section{Malignancies}

The thrombotic tendency generally observed in malignant diseases has been attributed to the release of thromboplastic substances from the tumour. ${ }^{117}$ However, tumoural cells are known to produce fibrinolytic agents. For example in vitro cultures of carcinoma of the ovary have been found to produce an agent immunologically identical to u-PA ${ }^{118}$ while melanoma cells produce an activator indifferentiable from t-PA. ${ }^{119}$ Tendency to thrombosis notwithstanding, the presence of tumoural plasminogen activator may be explained by recent studies showing that patients with malignancy have an increased plasma levels of t-PA inhibitor, ${ }^{120,121}$ a characteristic which is shared by patients with idiopathic venous thrombosis (see above).

\section{Miscellaneous conditions}

In Behçet's syndrome one third of the patients develop venous thrombosis. ${ }^{122}$ These patients have been found to have a depressed blood fibrinolysis ${ }^{123,124}$ and to release low amounts of plasminogen activator following vasogenic stimuli as injection of DDAVP, a vasopressin analogue. ${ }^{123}$

In 12 cases of thrombotic thrombocytopenic purpura plasminogen activator activity was found to be unmeasurably low but the levels of t-PA antigen were normal. ${ }^{125}$ The finding could be explained by the presence in all 12 cases examined of an inhibitor directed to t-PA and u-PA. Low levels of protein C antigen presumably had a contributory action to the decreased activity.

Oral contraceptives are known to be associated with an increased risk for thrombo- embolism and women taking p-pills have been found to have an impaired response to fibrinolytic stimuli such as venous stasis. ${ }^{126,127}$ However, in some women the depression of fibrinolysis is still present one year after cessation of p-pill intake, a fact suggesting a preexistent depression of fibrinolysis as previously suspected in these patients. ${ }^{128}$

\section{Comment}

While our knowledge about the fibrinolytic system has increased in the last few decades, our understanding of its main role in pathophysiology has remained at the stage of an assumption formulated in the mid 1950s, i.e. that fibrinolysis prevents thrombotic occlusion of blood vessels and promotes vascular recanalisation. ${ }^{129}$ The persisting uncertainty depends on the fact that such a role is very difficult to prove. The pathogenesis of thrombosis is widely multifactorial and therefore notoriously elusive. And, as regards the factor haemostasis, thrombotic occlusions have been linked not only to depressed fibrinolysis but also to platelet hyperaggregability, deficiency in antithrombin III, increased levels of fibrinogen, coagulation factor V, VII, VIII, ${ }^{130}$ deficiency of protein $\mathrm{C}$ or of its cofactor protein S. ${ }^{131}$ Finally, formation or dissolution fibrin in the organism results from the interplay of two complex systems, coagulation and fibrinolysis, each involving a vast number of activators and inhibitors. Such systems are efficiently buffered and do not usually decompensate following the decrease of one or more components. This situation, unlike the action of a defective enzyme on a given metabolic pathway, makes the consequence of fibrinolytic disorders especially arduous to identify.

The assumed role of fibrinolysis in the pathogenesis of other changes which are far more time consuming than thrombosis such as arteriosclerosis may well remain impossible to prove. Astrup's hypothesis of an equilibrium between fibrin formation and fibrinolysis prevailing in the whole vascular tree ${ }^{32}$ however appealing to our 'physiological common sense' is probably destined to remain at the stage of hypothesis for the foreseeable future.

A disturbing point is what one may call the 'bias of the positive result'. While embarking upon a study on fibrinolysis and vascular 
occlusion it is unavoidable for the investigator to entertain a certain hope that a connection between decreased fibrinolysis and thrombosis or tendency to thrombosis is going to be found. Even if such expectation does not, as it should not, influence the results it may well dissuade the continuation of the study, or discourage publication if negative results are obtained. In this way the reviewer, faced by an unbalanced body of evidence, is likely to add his voice to an artificial consensus.

Having said that, one has to underline that, while not proven, the antithrombotic role of fibrinolysis is suggested by an impressive amount of evidence. First of all the location of $\mathrm{t}$-PA in the endothelium of blood vessels, i.e. the most suitable site for counteracting thrombus formation and growth. Histochemistry provides a dramatic evidence of the fibrin-dissolving power of the vascular endothelium: one single endothelial cell contains sufficient t-PA rapidly to produce a gap in a $70 \mu \mathrm{m}$ thick fibrin film large enough to be visible to the naked eye. ${ }^{132}$ Faced by such a conspicuous action in vitro it seems unavoidable to attribute to the vascular endothelium a significant fibrinolytic (thrombolytic) function in vivo also. Recent clinical studies on patients with fresh coronary occlusion ${ }^{133}$ document angiographically that i.v. administration of t-PA has a thrombolytic effect. Some clinical cases are singularly convincing. For example, it is difficult not to connect two unusual conditions, i.e. widespread thrombosis in young subjects and high plasma levels of fibrinolytic inhibitors. ${ }^{21,22}$ Indirect evidence of the antithrombotic role of plasminogen activators is provided by numerous clinical observations that increased blood levels of $\mathrm{t}-\mathrm{PA} / \mathrm{u}-\mathrm{PA}$ is accompanied by the presence of fibrin degradation products (FDP) in plasma $^{134}$ or the occurrence of haemorrhages. ${ }^{135}$

It seems reasonable to expect that an increased knowledge about fibrinolysis is going to improve our ability of preventing thrombosis and inducing thrombolysis.

Key words: Fibrinolytic inhibitors, Fibrinolysis, Ischemia, Plasminogen activators, Thrombosis.

\footnotetext{
References

${ }^{1}$ Wallèn, P: Chemistry of plasminogen and plasmino-
}

gen activation. In: Progress in chemical fibrinolysis and thrombolysis. (Davidson JF, Rowan RM, Samama MM, Desnoyers PC eds), New York: Raven Press 1978: 167-81.

${ }^{2}$ Raum D, Marcus D, Alper CA, Levey R, Taylor PD, Starzl TE: Synthesis of human plasminogen by the liver. Science 1980, 208: 1036-7.

${ }^{3}$ Wallèn $\mathrm{P}$, Bergsdorf $\mathrm{N}$, Rånby $\mathrm{M}$ : Purification and identification of two structural variants of porcine tissue plasminogen activators by affinity adsorption on fibrin. Biochem Biophys Acta 1982, 719: 318-28.

${ }^{4}$ Husain SS, Gurewich V, Lipinski B: Purification and partial characterisation of a single-chain high molecular weight form of urokinase (UK) from human urine. Arch Biochem Biophys 1983, 220: 31-38.

${ }^{5}$ Pandolfi M: Histochemistry and assay of plasminogen activators. Europ J Clin Biol Res 1972, 17: $256-60$.

${ }^{6}$ Nilsson IM and Pandolfi M: Fibrinolytic response of the vascular wall. Thromb Diathes Haemorrh 1970, suppl 40: $231-42$.

${ }^{7}$ Booth NA, Walker E, Maughan R, Bennet B: Plasminogen activator in normal subjects after exercise and venous occlusion: t-PA circulates as complexes with C1-inhibitor and PAI-1. Blood 1987, 69: $1600-4$.

${ }^{8}$ Wijngaards G, Kluft C, Groeneveld E: Demonstration of urokinase-related fibrinolytic activity in human plasma. Br J Haemat 1982, 51: 165-9.

9 Åstedt B and Holmberg L: Immunological identity of urokinase and ovarian carcinoma plasminogen activator released in tissue culture. Nature 1976, 261: 595-7.

${ }^{10}$ Pandolfi $\mathrm{M}$ and Lantz E: Partial purification and characterisation of keratokinase, the fibrinolytic activator of the cornea. Exp Eye Res 1979, 29: 563-71.

${ }^{11}$ Kluft C: New prospects in the activation of fibrinolysis. In: Synthetic substrates in clinical blood coagulation assay. (Lijnen RH, Collen D, Verstreate M eds), The Hagues: Martinus Nijhof Publishers 1980: 113-22.

${ }^{12}$ Kluft C, Dooijewaard G, Emeis JJ: Role of the contact system in fibrinolysis. Seminars Thromb Haemostas 1987, 13: 50-68.

${ }^{13}$ Aoki N: Hemostasis associated with abnormalities of fibrinolysis. Blood Reviews 1989, 3: 11-17.

${ }^{14}$ Robbins K: The plasminogen-plasmin enzyme system. In: Hemostatis and thrombosis. (Coleman RW, Hirsh J, Marder VJ, Salzamm EW, eds), Philadelphia: JB Lippincott Co 1988: 340-357.

${ }^{15}$ Miles LA and Plow EF: Plasminogen receptors: Ubiquitous sites for cellular regulation of fibrinolysis. Fibrinolysis 1988, 3: 61-71.

${ }^{16}$ Juhan-Vague I, Aillaud MF, Serradimigni A: Natural inhibitors of fibrinolysis. Haemostasis 1986, 16 suppl 3: 16-20.

${ }^{17}$ Kruithof EKO: Plasminogen activator inhibitors-A review. Enzyme 1988, 40: 113-121.

${ }^{18}$ Sprengers ED and Kluft C: Plasminogen activator inhibitors. Blood 1987, 69: 381-7. 
${ }^{19}$ Grimaudo V, Hauert J, Bachmann F, Kruithof EKO: Diurnal variation of the fibrinolytic system. Thromb Haemostas 1988, 59: 495-9.

${ }^{20}$ Lecander I and Åstedt B: Occurrence of a specific plasminogen activator inhibitor of placental type, PAI-2, in men and non-pregnant women. Fibrinolysis 1989, 3: 27-9.

${ }^{21}$ Zolton RP and Seegers WH. Autoprothrombin II-A: Thrombin removal and mechanism of induction of fibrinolysis. Thromb Res 1973, 3: 23-33.

${ }^{22}$ Comp PC and Esmon T: Generation of fibrinolytic activity by infusion of activated protein $\mathrm{C}$ into dogs. J Clin Invest 1981, 68: 1221-8.

${ }^{23}$ Sakata Y, Curriden S, Lawrence D, Griffin JH, Loskutoff DJ: Activated protein $\mathrm{C}$ stimulates the fibrinolytic activity of cultured endothelial cells and decreases antiactivator activity. Proc Natn Acad Sci USA 1985, 82: 1121-5.

${ }^{24}$ De Fouw NJ, Haverkate F, Bertina RM, Koopman J, van Wijngaarden A, van Hinsberg VWM: The cofactor role of protein $S$ in the acceleration of the whole clot lysis by activated protein $\mathrm{C}$ in vitro. Blood 1986; 67: 1189-92.

${ }^{25}$ Saito H: Alpha 2 -plasmin inhibitor and its deficiency states. J Lab Clin Med 1988, 112: 671-7.

${ }^{26}$ Müllertz S: Role of alpha $a_{2}$-macroglobulin as an inhibitor of fibrinolysis. In: The physiological inhibitors of blood coagulation and fibrinolysis. (Collen D, Wiman B, Verstreate M, eds), Amsterdam: Elsevier 1979: 243-5.

${ }^{27}$ Wiman B: Human C1-inhibitor. In: Proteinase inhibitors. (Barret AJ, Salvesen G, eds), Amsterdam: Elsevier 1986: 477-88.

${ }^{28}$ van Hinsberg VWM: Regulation of the synthesis and secretion of plasminogen activators by endothelial cells. Haemostasis 1988, 18: 307-27.

${ }^{29}$ Beebe DP: Binding of tissue plasminogen activator to human umbilical vein endothelial cells. Thromb Res 1987, 46: 241-54.

${ }^{30}$ Blasi F: Surface receptors for urokinase plasminogen activator. Fibrinolysis 1988, 2: 73-84.

${ }^{31}$ Astrup T: Fibrinolysis in the organism. Blood 1956, 11: 781-93.

${ }^{32}$ Astrup T: The haemostatic balance. Thromb Diathes Haemorrh 1958, 2: 347-57.

${ }^{33}$ Pandolfi M: Haemorrhages in ophthalmology. A haemostatic approach. Stuttgart. Thieme 1974: 18-9.

${ }^{34}$ Nilsson IM, Krook H, Sternby NH, Soederberg E, Soedestroem N: Severe thrombotic disease in a young man with bone marrow and skeletal changes and with a high content of an inhibitor in the fibrinolytic system. Acta Med Scand 1961, 169: 323-37.

${ }^{35}$ Nilsson IM: The development of thrombosis. In: Stroke. Thule International Symposia. Stockholm Sweden: Nordiska Bokhandel 1967: 215-222.

${ }^{36}$ Pandolfi M, Isacson S, Nilsson IM: Low fibrinolytic activity in the walls of vein in patients with thrombosis. Acta Med Scand 1969, 168: 1-5.

${ }^{37}$ Pandolfi M, Hedner U, Nilsson IM: Bilateral occlusion of the retinal veins in a patient with inhibition of fibrinolysis. Ann Ophthalmol 1970, 1: 481-4.
${ }^{38}$ Isacson S and Nilsson IM: Defective fibrinolysis in blood and vein walls in recurrent 'idiopathic' venous thrombosis. Acta Chir Scand 1972, 138: 313-19.

${ }^{39}$ Johansson L, Hedner U, Nilsson IM: A family with thromboembolic disease associated with deficient fibrinolytic activity in vessel wall. Acta Med Scand 1978, 203: 477-80.

${ }^{40}$ Sundqvist SB, Hedner U, Kullenberg HKE, Bergenz SE: Deep venous thrombosis of the arm: A study of coagulation and fibrinolysis. $\mathrm{Br}$ Med $\mathrm{J}$ 1981, 283: 265-7.

${ }^{41}$ Conard J, Veuillet-Duval A, Horellou MH, Samama M: Etude de la coagulation et de la fibrinolyse dans 131 thromboses veineuses recidivantes. Rev Fr Hematol 1982, 24: 205-9.

${ }^{42}$ Jørgensen M, Mortensen JZ, Madsen AG, Thorsen S, Jacobsen B: A family with reduced plasminogen activator in blood associated with recurrent venous thrombosis. Scand J Haematol 1982, 29: 217-23.

${ }^{43}$ Stead NW, Bauer KA, Kinney TR, Lewis JG, Campbell EE, Shifman MA, Rosenberg RD, Pizzo SV: Venous thrombosis in a family with defective release of vascular plasminogen activator and elevated plasma factor VIII/von Willebrand's factor. Am J Med 1983, 74: 33-9.

${ }^{44}$ Brommer EJP, Verheijen JH, Chang GTG, Rijken DC: Masking the fibrinolytic response to stimulation by an inhibitor of tissue-type plasminogen activator in plasma. Thromb Haemost 1984, 62: 154-6.

${ }^{45}$ Nilsson IM, Ljungner $\mathrm{H}$, Tengborn L: Two different mechanisms in patients with venous thrombosis and defective fibrinolysis: Low concentration of plasminogen activator or increased concentration of plasminogen activator inhibitor. Brit Med J 1985, 290: 1453-6.

${ }^{46}$ Juhan-Vague I, Valadier J, Alessi MC, Aillaud MF, Ansaldi J, Philip-Joet C, Holvoet P, Serradimigni A, Collen D: Deficient t-PA release and elevated PA inhibitor levels in patients with spontaneous or recurrent deep venous thrombosis. Thromb Haemost 1987, 57: 67-72.

${ }^{47}$ Wiman B, Chmielewska J: A novel fast inhibitor to tissue plasminogen activator in plasma which may be of great pathophysiological significance. Scand J Clin Lab Invest 1985, 45 Suppl 177: 43-7.

${ }^{48}$ Wiman B, Ljungberg B, Chmielewska J, Urden G, Blombæck M, Johnsson $\mathrm{H}$ : The role of the fibrinolytic system in deep venous thrombosis. $J$ Lab Clin Med 1985, 105: 267-70.

${ }^{49}$ Nilsson IM and Tengborn L: Impaired fibrinolysis. New evidence in relation to thrombosis. Clinical aspects of fibrinolysis and thrombolysis. (Jespersen J, Kluft C, Korgaard O, eds), Esbjerg: South Jutland University Press, 1983: 273-91.

${ }^{50}$ Petäjä J, Rasi V, Myllyalä G, Vahtera E, Hallman $\mathrm{H}$ : Familial hypofibrinolysis and venous thrombosis. Brit J Haemat 1989, 71: 393-8.

${ }^{51}$ Jørgensen $\mathbf{M}$ and Bonnevie-Nielsen V: Increased concentration of the fast-acting plasminogen activator inhibitor in plasma associated with familial venous thrombosis. $B r J$ Haemat 1987, 65: 175-80. 
${ }^{52}$ Aoki N, Moroi M, Sakata Y, Yoshida N: Abnormal plasminogen. A hereditary molecular abnormality found in a patient with recurrent thrombosis. $J$ Clin Invest 1978, 61: 1186-95.

${ }^{53}$ Aoki N: Fibrinolysis. Its mutation and regulation. $J$ Prot Chem 1986, 5: 269-77.

${ }^{54}$ Aoki N: Genetic abnormalities of the fibrinolytic system. Seminars in thrombosis and hemostasis, 1984; 10: 42-50.

${ }^{55}$ Lottenberg R, Dolly FR, Kitchens CS: Recurring thromboembolic disease and pulmonary hypertension associated with severe hypoplasminogenemia. Am J Hematol 1985, 19: 181-93.

${ }^{56}$ Griffin JH, Evatt B, Zimmerman TS, Kleiss AJ: Deficiency of protein $\mathrm{C}$ in congenital thrombotic disease. J Clin Invest 1981, 68: 1370-3.

${ }^{57}$ Jespersen J, Gram J, Bertina RM: The risk of thrombosis in hereditary protein $\mathrm{S}$ deficiency in a Scandinavian family. Fibrinolysis 1989, 3: 37-40.

${ }^{58}$ De Wood MA, Spores J, Notske R, Mouser LT, Burroughs R, Golden MS, Lang HT: Prevalence of total coronary occlusion during the early hours of transmural myocardial infarction. $N$ Engl J Med 1980, 303: 897-902.

${ }^{59}$ Sherman CT, Litvack F, Grundfest W: Coronary angioscopy in patients with unstable angina pectoris. $N$ Engl J Med 1985, 315: 913-9.

${ }^{60}$ Hugenholtz PG and Suryapranata H: Thrombolytic agents in early myocardial infarction. Am J Cardiol 1989, 63: 94E-101E.

${ }^{61}$ Merskey C, Gordon H, Lackner H: Blood coagulation and fibrinolysis in relation to coronary heart disease. Br Med J 1960, 1: 219-27.

${ }^{62}$ Chakrabarti R, Hocking ED, Fearnley GR: Fibrinolytic activity and coronary artery disease. Lancet 1968, ii: 987-90.

${ }^{63}$ Walker ID, Davidson JF, Hutton I, Lawrie TDV: Disordered 'fibrinolytic potential' in coronary artery disease. Thromb Res 1977, 10: 509-20.

${ }^{64}$ Hamsten A, Wiman B, de Faire U, Blombäck M: Increased plasma levels of a rapid inhibitor of tissue plasminogen activator in young survivors of myocardial infarction. $N$ Engl J Med 1985, 313: 1557-63.

${ }^{65}$ Francis RB, Kawanishi D, Baruch T, Mahrer P, Rahimtoola S, Feinstein DI: Impaired fibrinolysis in coronary artery disease. Am Heart J 1988, 115: 776-80.

${ }^{66}$ Hamsten A, Walldius G, Szamosi A, Blombæck M, de Faire U, Dahlen G, Wiman B: Plasminogen activator inhibitor in plasma: Risk factor for recurrent myocardial infarction. Lancet 1987, ii: 3-9.

${ }^{67}$ Meade TW, Chakrabarty R, Haines AP, North WRS, Stirling Y: Characteristics affecting fibrinolytic activity and plasma fibrinogen concentration. Br Med J 1979, 1: 153-6.

${ }^{68}$ Andersen P, Arnesen H, Hjermann I: Hyperlipoproteinemia and reduced fibrinolytic activity in healthy coronary high-risk men. Acta Med Scand 1981, 209: 199-202.

${ }^{69}$ Simpson HCR, Mann JI, Meade TW, Chakrabarti R, Stirling Y, Wolf L: Hypertriglyceridemia and hypercoagulability. Lancet 1983, i: 789-9.
${ }^{70}$ Oseroff A, Krishnamurti C, Hasset A, Tang D, Alving B: Plasminogen activator and plasminogen activator inhibitor activities in men with coronary artery disease. J Lab Clin Med 1989, 113: 88-93.

${ }^{71}$ Kirschstein W, Simianer S, Dempfle CE, Keller H, Stegaru B, Rentrop P, Heene DL: Impaired fibrinolytic capacity and tissue plasminogen activator release in patients with restenosis after percutaneous transluminal coronary angioplasty (PTCA). Thrombosis and Haemostasis 1989, 62: 772-75.

${ }^{72}$ Anderson LA and Gormsen J: Platelet aggregation and fibrinolytic activity in transient cerebral ischemia. Acta Neurol Scand 1976, 55: 76-82.

${ }^{73}$ Mettinger KL and Egberg N: A study of haemostasis in ischemic cerebrovascular disease. Abnormalities in vascular plasminogen activators, antiactivators and alpha-2-antiplasmin. Thromb Res 1982, 26: 203-10.

${ }^{74}$ Bertelè V, Mussoni L, del Rosso G, Pintucci MR, Carrero MG, Merati, Libretti A, G de Gaetano G: Defective fibrinolytic response in atherosclerotic patients. Effect of iloprost and its possible mechanism of action. Thrombosis and Haemostasis 1988, 60: 141-4.

${ }^{75}$ Towne JB, Hussey CV, Bandyck DF: Abnormalities of the fibrinolytic system as a cause of upper limb ischemia: A preliminary report. J Vasc Surg 1988, 7: 661-6.

${ }^{76}$ Earnshaw JJ, Westby JC, Hopkinson BR, Makin GS: Resting plasma fibrinolytic activity and fibrinolytic potential in peripheral vascular disease. $J$ Cardiovasc Surg 1988, 29: 300-5.

${ }^{77}$ Ljungner $\mathrm{H}$ and Bergquist $\mathrm{D}$ : Decreased fibrinolytic activity in human atherosclerotic vessels. Atherosclerosis 1984, 50: 113-6.

${ }^{78}$ Jacobs GR, Reinisch JF, Puckett CL: Microvascular fibrinolysis after ischemia: Its relation to vascular patency and tissue survival. Plastic Reconstr Surg 1981, 68: 734-41.

${ }^{79}$ Åstedt B: On fibrinolysis. A in pregnancy, labour, puerperium, and during treatment with sex hormones. B. In human ontogenesis and in human organ culture. Acta Obst Gyn Scand 1972, 51, Suppl. 18.

${ }^{80}$ Åstedt B, Isacson S, Nilsson IM, Pandolfi M: Fibrinolytic activity of veins during pregnancy. Acta Obst Gyn Scand 1970, 49: 171-3.

${ }^{81}$ Åstedt B: Significance of placenta in depression of fibrinolytic activity during pregnancy. $\mathrm{J}$ Obstet Gynaecol 1972, 79: 205-6.

${ }^{82}$ Philips M, Juul AG, Thorsen S, Selmer J, Zenthen $\mathrm{J}$ : Immunological relationship between the fastacting plasminogen activator inhibitors from plasma, blood platelet and endothelial cells demonstrated with a monoclonal antibody against an inhibitor from placenta. Thromb Haemost 1986, 55: 213-7.

${ }^{83}$ Åstedt B, Lecander I, Brodin T, Lundblad A, Löw $\mathrm{K}$ : Purification of a specific placental plasminogen activator inhibitor by monoclonal antibody and its complex formation with plasminogen activator. Thromb and Haemost 1985, 53: 122-5.

${ }^{84}$ Wiman B, Csemicsky G, Marsk L, Robbe H: The fast inhibitor of tissue plasminogen activator in 
plasma during pregnancy. Thromb Haemostas 1984, 52: 124-126.

${ }^{85}$ Lecander I, Åstedt B: Isolation of a new specific plasminogen activator inhibitor from pregnancy plasma. Br J Haematol 1986, 62: 221-8.

${ }^{86}$ Almer LO, Janzon L: Low vascular fibrinolytic activity in obesity. Thromb Res 1975, 6: 171-5.

${ }^{87}$ Vague P, Juhan-Vague I, Aillaud MF, Badier C, Viard S, Alessi MC, Collen D: Correlation between blood FA, PA-inhibitor levels, plasma insulin level and relative body weight in normal and obese subjects. Metabolism 1986, 35: 250-3.

${ }^{88}$ Vague P, Juhan-Vague I, Alessi M, Badier C, Viard S, Alessi MC, Valadier J: Metformin decreases the high PA inhibitor capacity, plasma insulin and triglyceride level in non-diabetic obese subjects. Thromb Haemost 1987, 57: 326-8.

${ }^{89}$ Legnani C, Maccaferri M, Tonini P, Cassio A, Coccheri S: Reduced fibrinolytic response in obese children: Association with high baseline activity of the fast acting PA inhibitor (PAI-1). Fibrinolysis 1988, 2: 211-14.

${ }^{90}$ Grace CS: Fibrinolysis and obesity: The effect of weight reduction. Aust Ann Med 1985, 18: 32-5.

${ }^{91}$ WIlliams RS, Logue EE, Lewis JL, Barton T, Stead NW, Wallace AG, Pizzo SV: Physical conditioning augments the fibrinolytic response to venous occlusion in healthy adults. N Engl J Med 1980, 302: 987-91.

${ }^{92}$ Marsh N: Fibrinolysis. Chichester: John Wiley and Sons, 1981: 102.

${ }^{93}$ Miles LA, Fless GM, Levin EG, Scanu A, Plow EF: A potential basis for the thrombotic risk associated with lipoproteinen(a). Nature 1989, 339: 301-2.

${ }^{94}$ Kluft C, de Bart ACW, Barthels M, Sturm J, Moeller W: Short term increase in plasminogen activator inhibitor 1 (PAI-1) in plasma of polytrauma patients. Fibrinolysis 1988, 2: 223-6.

${ }^{95}$ Kapsch DN, Metzler M, Harrington M, Mitchell FL, Silver D: Fibrinolytic response to trauma. Surgery 1984, 95: 473-8.

${ }^{96}$ Sautter RD, Myers WO, Ray JF, Wenzel FJ: Relationship of fibrinolytic system to postoperative thrombotic phenomena. Arch Surg 1973, 107: 292-6.

${ }^{97}$ Rem J, Feddersen C, Brandt MR, Kehlet H: Postoperative changes in coagulation and fibrinolysis independent of neurogenic stimuli and adrenal hormones. Br J Surg 1981, 68: 229-33.

${ }^{98}$ Ljugner $\mathrm{H}$, Bergqvist D, Isacson S: Plasminogen activator activity in patients undergoing transvescical and transurethral prostatectomy. Eur Urol 1983, 9: 24-7.

${ }^{99}$ Clayton JK, Anderson JA, McNicol GP: Preoperative prediction of postoperative deep venous thrombosis. Br Med J 1976, 2: 912.

${ }^{100}$ Rakoczi I, Chamone D, Collen D, Verstreate M: Prediction of postoperative leg-vein thrombosis in gynaecological patients. Lancet 1978, i: 509-10.

${ }^{101}$ Comp PC, Jacocks RM, Taylor FB: The diluted whole clot lysis assay: A screening method for identifying postoperative patients with a high incidence of deep venous thrombosis. J Lab Clin Med 1979, 93: 120-7.
${ }^{102}$ Crandon AJ, Peel KR, Anderson JA, Thompson V, McNicol GP: Postoperative deep venous thrombosis: Identifying high-risk patients. $\mathrm{Br} \mathrm{Med} J$ 1980, 2: 343-4

${ }^{103}$ Sue-Ling HM, Johnston D, McMahon MJ, Philps PR, Davies JA: Pre-operative identification of patients at high risk of deep venous thrombosis after elective major abdominal surgery. Lancet 1986, i: $1173-6$.

${ }^{104}$ Gore M, Miller K, S Soong, Clarke-Pearson DL, Pizzo SV: Vascular plasminogen activator levels and thromboembolic disease in patients with gynecologic malignancies. Am J Obstet Gynecol 1984, 149: 830-4.

${ }^{105}$ Mellbring G, Dahlgren S, Reiz S, Wiman B: Fibrinolytic activity in plasma and deep venous thrombosis after major abdominal surgery. Thromb Res 1983, 32: 575-84.

${ }^{106}$ Aillaud MF, Juhan-Vague I, Alessi MC, Marecal M, Vinson MF, Arnaud C, Vague P, Collen D Increased PA-inhibitor levels in the postoperative period-no cause-effect relation with increased cortisol. Thromb Haemost 1985, 54: 466-8.

${ }^{107}$ Kluft C, Veheijen JH, Jie AFH, Rijken DC, Preston FE, Sue-Ling HM, Jespersen J, Aasen AO: The postoperative fibrinolytic shutdown: A rapidly reverting acute phase pattern for the fastacting inhibitor of tissue-type plasminogen activator after trauma. Scand J Clin Lab Invest 1985 , 45: 605-10.

${ }^{108}$ Paramo JA, Alfaro MJ, Rocha E: Postoperative changes in the plasmatic levels of tissue-type plasminogen activator and its fast-acting inhibitorrelationship to deep venous thrombosis and influence of prophylaxis. Thromb Haemost 1985, 54: 713-6.

${ }^{109}$ Juhan-Vague I, Moerman B, De Cock F, Aillaud MF, Collen D: Plasma levels of a specific inhibitor of tissue type plasminogen activator (and urokinase) in normal and pathological conditions. Thromb Res 1984, 33: 523-30.

${ }^{110}$ Elias $M$ and Eldor A: Thromboembolism in patients with the 'lupus'-type circulating anticoagulant. Arch Int Med 1984, 144: 510.

${ }^{111}$ Lechner K: Lupus anticoagulant and thrombosis. In Verstreate M, Vermylen J, Lijnen HR, Arnout J, eds. Thrombosis and Hemostasis. Leuven: Leuven University Press, 1987, 525-47.

${ }^{112}$ Angles-Cano E, Sultan Y, Clauvel JP: Predisposing factors to thrombosis in systemic lupus erythematosous. Possible relation to endothelial damage. $J$ Lab Clin Med 1979, 94: 312-23.

${ }^{113}$ Nilsson TK and Løfvenberg E: Decreased fibrinolytic capacity and increased von Willebrand factor levels as indicators of endothelial cell dysfunction in patients with lupus anticoagulant. Clin Rheumatol 1988, 8: 58-63.

${ }^{114}$ Tsakiris DA, Marbet GA, Makris PE, Settas L, Duckert F: Impaired fibrinolysis as an essential contribution to thrombosis in patients with lupus anticoagulant. Thromb Haemostas 1989, 61: 175-7.

${ }^{115}$ Awada H, Barlowatz-Meimon G, Dougados M, Maisonneuve P, Sultan Y, Amor B: Fibrinolysis 
abnormalities in systemic luipus erythematosus and their relation to vasculitis. J Lab Clin Med 1988, 111: 229-36.

${ }^{116}$ Francis RB, McGehe WG, Feinstein D: Endothelial-dependent fibrinolysis in subjects with lupus anticoagulant and thrombosis. Thrombos Haemostasis 1988, 59: 412-4.

${ }^{117}$ Marsh N: Fibrinolysis. Chichester: John Wiley and Sons 1981,140

118 Åstedt B and Holmberg L: Immunological identity of urokinase and ovarian carcinoma plasminogen activator released in tissue culture. Nature 1976, 261: 595-7.

${ }^{119}$ Rijken DC, Collen D: Purification and characterisation of the plasminogen activator from a human melanoma cell culture. In: Progress in Fibrinolysis. (Davidson JF, Nilsson IM, Åstedt B, eds), Edinburgh: Churchill Livingstone 1981: vol. 5: 236-9.

${ }^{120}$ Juhan-Vague I, Moerman B, De Cock F, Aillaud MF, Collen D: Plasma levels of a specific inhibitor of tissue type plasminagen activator (and urokinase) in normal and pathological condition. Thromb Res 1984, 33: 523-30.

${ }^{121}$ Kirchheimer JC, Huber K, Wagner O, Binder BR: Pattern of fibrinolytic parameters in patients with gastrointestinal carcinomas. Brit J Haemat 1987, 66: $85-9$.

${ }^{122}$ Kluft C, Michiels JJ, Wijngaards G: Artificial inhibition of fibrinolysis and occurrence of venous thrombosis in three cases of Behçet's disease. Scand J Haematol 1980, 25: 423-30.

${ }^{123}$ Schmitz-Huebner U, Knop J : Evidence for an endothelial cell dysfunction in association with Behçet's disease. Thromb Res 1984, 34: 277-85.

${ }^{124}$ Mishima H, Masuda K, Shimada S, Toki N, Tsushima H, Gocho M: Plasminogen activator activity levels in patients with Behçet's disease. Arch Ophthalmol 1985, 103: 935-6.

${ }^{125}$ Glas P, Hall JM, Panke TW, Shashi KK, Allen CM,
Pollak VE: Fibrinolysis in health and disease: Abnormal levels of plasminogen activator inhibitor, and protein $\mathrm{C}$ in thrombotic thrombocytopenic purpura. J Lab Clin Med 1986, 108: 415-22.

${ }^{126}$ Miller KE and Pizzo SV: Venous and arterial thromboembolic disease in women using oral contraceptives. Am J Obstet Gynecol 1982, 144: 824-7.

${ }^{127}$ Pizzo SV, Lewis JC, Cambell EE, Dreyer NA: Fibrinolytic response and oral contraceptives associated thromboembolism.Contraception 1981, 23: 181-6.

128 Åstedt B, Isacson S, Nilsson IM, Pandolfi M: Women with previous thrombosis during use of pills-were they predisposed? Brit Med J 1973, 141: 631-3.

${ }^{129}$ Astrup T: Fibrinolysis in the organism. Blood 1956, 11: 781-9.

${ }^{130}$ Nilsson IM: Haemorrhagic and thrombotic diseases. London: John Wiley and Sons 1971, 164-6.

${ }^{131}$ Geiger M: Protein C inhibitor/plasminogen activator inhibitor 3. Fibrinolysis 1988, 2: 183-8.

${ }^{132}$ Pandolfi M, Bjernstad A, Nilsson IM: Technical remarks on the microscopical demonstration of tissue plasminogen activator. Thrombos Diathes Haemorrh 1972, 27: 88-98.

${ }^{133}$ Verstreate M, Bleifeld W, Brower RW, Charbonnier B, Collen D, de Bono AP, Dunning AJ, Lennane RJ, Lubsen J, Mathey DG, Michel PL, Raynaud P, Schofer J, Vahanian A, Vanhaecke J, Van de Kley GA, Van de Werf F, Von Essen R: Double blind randomised trial of intravenous tissue-type plasminogen activator versus placebo in acute myocardial infarction. Lancet 1985, ii: 965-9.

${ }^{134}$ Nilsson IM: Haemorrhagic and thrombotic diseases. London: John Wiley and Sons 1971 , 133-40

${ }^{135}$ Bennet B, Booth NA, Croll A, Dawson AA: The bleeding disorder in acute promyelocytic leukaemia: Fibrinolysis due to u-PA rather than defibrination. Brit J Haematol 1989, 71: 511-7. 